\title{
Agronomic performance of soybean grown in succession to winter cover crops
}

\author{
Fábio Henrique Krenchinski(1), Victor José Salomão Cesco(1), Danilo Morilha Rodrigues(1), \\ Leandro Paiola Albrecht ${ }^{(2)}$, Katle Samaya Wobeto ${ }^{(2)}$ and Alfredo Júnior Paiola Albrecht ${ }^{(2)}$
}

\begin{abstract}
(1)Universidade Estadual Paulista, Faculdade de Ciência Agronômicas, Campus de Botucatu, Fazenda Lageado, Avenida Universitária, no 3.780, Altos do Paraíso, CEP 18610-034 Botucatu, SP, Brazil. E-mail: fhkrenchinski@gmail.com, victorcesco@hotmail.com, danilomorlharodrigues@hotmail.com (2)Universidade Federal do Paraná, Setor Palotina, Rua Pioneiro, no 2.153, CEP 85950-000 Palotina, PR, Brazil. E-mail: Ipalbrecht@yahoo.com, katle_samaya@hotmail.com, ajpalbrecht@yahoo.com
\end{abstract}

\begin{abstract}
The objective of this work was to evaluate the effect of winter cover crop species on the agronomic performance of soybean (Glycine max) cropped in succession, under a no-tillage system. The study was conducted during three crop seasons (2011/2012, 2012/2013, and 2013/2014), with the following cover crops: white oat (Avena sativa), black oat (Avena strigosa), ryegrass (Lolium multiflorum), vetch (Vicia sativa), forage radish (Raphanus sativus), the intercrop black oat + forage radish, and wheat (Triticum aestivum) as the standard management. Forage radish and the intercrop black oat + forage radish provided greater soil cover rates after 30 days of planting, as well as dry matter production in the three crop seasons. After 45 and 90 days from desiccation, however, white oat and ryegrass showed the highest soil cover rate. Black oat and the intercrop black oat + forage radish provided higher soybean yield than the standard management with wheat, in the 2012/2013 and 2013/2014 crop seasons. Winter cover crops can significantly affect soybean yield in succession, and black oat and the intercrop black oat + forage radish stand out for this purpose.
\end{abstract}

Index terms: Glycine max, crop rotation, mulching, no-tillage, soil cover.

\section{Desempenho agronômico de soja cultivada em sucessão a espécies de cobertura de inverno}

\begin{abstract}
Resumo - O objetivo deste trabalho foi avaliar o efeito de espécies de cobertura de inverno no desempenho agronômico de soja cultivada em sucessão, sob plantio direto. $\mathrm{O}$ trabalho foi realizado durante três safras (2011/2012, 2012/2013 e 2013/2014), com os seguintes cultivos de cobertura: aveia-branca (Avena sativa), aveia-preta (Avena strigosa), azevém (Lolium multiflorum), ervilhaca (Vicia sativa), nabo-forrageiro (Raphanus sativus), consórcio de aveia-preta + nabo-forrageiro e trigo (Triticum aestivum) como manejopadrão. O nabo-forrageiro e o consórcio aveia-preta + nabo-forrageiro proporcionaram maiores percentagens de cobertura do solo após 30 dias do plantio, bem como produção de matéria seca nas três safras. Após 45 e 90 dias da dessecação, no entanto, a aveia-branca e o azevém apresentaram a maior taxa de cobertura do solo. A aveia-preta e o consórcio aveia-preta + nabo-forrageiro proporcionaram maior produtividade de soja que o manejo-padrão com trigo, nas safras de 2012/2013 e 2013/2014. As espécies de cobertura do solo afetam significativamente a produção de soja cultivada em sucessão, com destaque para a aveia-preta e o consórcio aveia-preta + nabo-forrageiro.
\end{abstract}

Termos para indexação: Glycine max, rotação de culturas, adubação verde, plantio direto, cobertura do solo.

\section{Introduction}

Using crop rotation in a productive system (Debiasi et al., 2010) has many benefits, such as: soil quality maintenance; reduction of pests, diseases, and weeds; agriculture diversification, reducing risks of crop failures; greater yields and, consequently, lower costs; and the efficient use of production factors.

In the agricultural areas of Southern Brazil, common practices are sowing winter cover crops in fall, preferentially under mild temperatures (Ziech et al., 2015), and cultivating soybean [Glycine $\max$ (L.) Merr.] or corn (Zea mays L.) monoculture, followed by wheat (Triticum aestivum L.) succession during winter. However, the later activity has a potentially negative impact on crop yields over time, increasing the need for the implementation of crop systems that include plant species with aggressive root systems and with a high dry matter production. 
Specifically in the western region of the state of Paraná, one of the country's largest soybean producers, the use of corn in the off-season is prevalent, mostly under the no-tillage system. However, the use of corn and wheat in succession to soybean, in the off-season, can limit the soybean cultivation system, reducing grain yield. In this scenario, using species properly adapted to each agricultural region can maximize soybean yield in the crop succession system.

Some winter cover crops have beneficial effects on the soybean summer crop. White oat (Avena sativa L.) and black oat (Avena strigosa Schreb.), for example, can add as much as $3.0-4.0 \mathrm{Mg} \mathrm{ha}^{-1}$ dry matter to the soil (Ziech et al., 2015). Cash crops can also be used in winter, as is the case of wheat, which can speed the sowing of soybean due to the lower amount of dry matter added to the soil, compared with black oat, successfully promoting the development of the legume (Santos \& Reis, 1991). Several authors have emphasized the importance of crop succession with cover crop species for soybean management systems, enhancing crop development and yield (Fontaneli et al., 2000; Pereira et al., 2011; Santos et al., 2013b; Costa et al., 2015).

The permanent cover of the soil with plants or plant residues is one of the main contributions of cover crops to the no-tillage system. Therefore, species with high initial growth, that produce a great amount of dry matter, and whose residues remain on the soil for as long as possible are desirable. However, the effects of cover crops on the production system and, more importantly, on soybean crop performance still need to be better understood. It should also be noted that studies evaluating the succession of crops over a long period of time are scarce or nonexistent for some regions.

The objective of this work was to evaluate the effect of winter cover crop species on the agronomic performance of soybean cropped in succession, under a no-tillage system.

\section{Materials and Methods}

The study was carried out in the field, in the municipality of Marechal Cândido Rondon

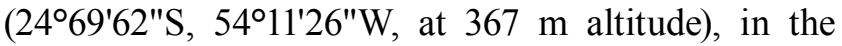
state of Paraná, Brazil, over the 2011/2012, 2012/2013, and 2013/2014 crop seasons. The soil is classified as a Latossolo Vermelho eutroférrico (Santos et al., 2013a), i.e., a Typic Eutrodox, and the climate, as Cfa, according to Köppen's classification.

The chemical and textural analyses $(0.00-0.20 \mathrm{~m})$ showed the following results: $\mathrm{pH}\left(\mathrm{CaCl}_{2}\right)$ 5.6, 7.86 $\mathrm{cmol}_{\mathrm{c}} \mathrm{dm}^{-3} \mathrm{Ca}, 3.26 \mathrm{cmol}_{\mathrm{c}} \mathrm{dm}^{-3} \mathrm{Mg}, 1.68 \mathrm{cmol}_{\mathrm{c}} \mathrm{dm}^{-3}$ $\mathrm{K}, 0.00 \mathrm{cmol}_{\mathrm{c}} \mathrm{dm}^{-3} \mathrm{Al}$, cation exchange capacity of $16.67 \mathrm{cmol}_{\mathrm{c}} \mathrm{dm}^{-3}, 36.55 \mathrm{~g} \mathrm{dm}^{-3}$ soil organic matter, base saturation of $71.27 \%, 19.40 \mathrm{mg} \mathrm{dm}^{-3} \mathrm{P}, 22.29 \mathrm{mg} \mathrm{dm}^{-3}$ $\mathrm{Fe}, 44.22 \mathrm{mg} \mathrm{dm}^{-3} \mathrm{Mn}, 12.51 \mathrm{mg} \mathrm{dm}^{-3} \mathrm{Cu}, 3.84 \mathrm{mg} \mathrm{dm}^{-3}$ $\mathrm{Zn}, 607.5 \mathrm{~g} \mathrm{~kg}^{-1}$ clay, $235.0 \mathrm{~g} \mathrm{~kg}^{-1}$ silt, and $157.5 \mathrm{~g} \mathrm{~kg}^{-1}$ sand.

Data on rainfall and maximum and minimum temperatures, in the three crop seasons, were collected daily, but pooled into 15-day periods (Figure 1).

The experimental design was a randomized complete block, with four replicates. The treatments consisted of the cover crops white oat, black oat, ryegrass (Lolium multiflorum Lam.), vetch (Vicia sativa L.), forage radish (Raphanus sativus L.), and black oat intercropped with forage radish. Wheat (Triticum aestivum L.) was considered the standard management. The plots were $4 \times 6 \mathrm{~m}$, disregarding $0.5 \mathrm{~m}$ of each end, totaling $15 \mathrm{~m}^{2}$.

The cover crop species and the wheat were hand sown in the first fortnight of May, with $20 \mathrm{~cm}$ between rows for all crops, in all crop seasons evaluated. The number of seeds per meter, however, followed the recommendations for each species: 55 for black oat, 60 for white oat, 240 for ryegrass, 30 for vetch, 20 for forage radish, $35+15$ for black oat + forage radish, and 65 for wheat (Fontaneli et al., 2000; Carneiro et al., 2008; Heinz et al., 2011; Pereira et al., 2011). During the development of the cover crops, the plots were kept free from weed interference, by hand weeding when necessary.

The cover species were desiccated 20 days after full bloom, using 1,080 $\mathrm{g} \mathrm{ha}^{-1}$ acid equivalent (a.e.) of glyphosate, with a spray volume of $200 \mathrm{~L} \mathrm{ha}^{-1}$. The wheat crop, however, was not desiccated; instead, it was harvested and only its residues were left in the area.

The SYN1059 (VTop) soybean cultivar was planted in the first half of October, in all crop seasons, using 350,000 seeds per hectare. Fertilization was done with $250 \mathrm{~kg} \mathrm{ha}^{-1}$ of $02-20-20 \mathrm{~N}-\mathrm{P}_{2} \mathrm{O}_{5}-\mathrm{K}_{2} \mathrm{O}$. The soybean crop was managed according to the recommendations of Tecnologias... (2010). Weed control was carried out using $720 \mathrm{~g} \mathrm{ha}^{-1}$ a.e. of glyphosate at the V4 stage and hand weeding whenever necessary, during 
the remainder of the cycle. The plots consisted of nine soybean rows with $6.0 \times 0.45-\mathrm{m}$ spacing. For the evaluations, seven $4-\mathrm{m}$ rows were used, totaling a useful area of $12.6 \mathrm{~m}^{2}$.
The analyzed variables were: percentage of soil cover 30 days after sowing, dry matter mass before desiccation of the species, and permanence of straw on soil surface 45 and 90 days after desiccation.
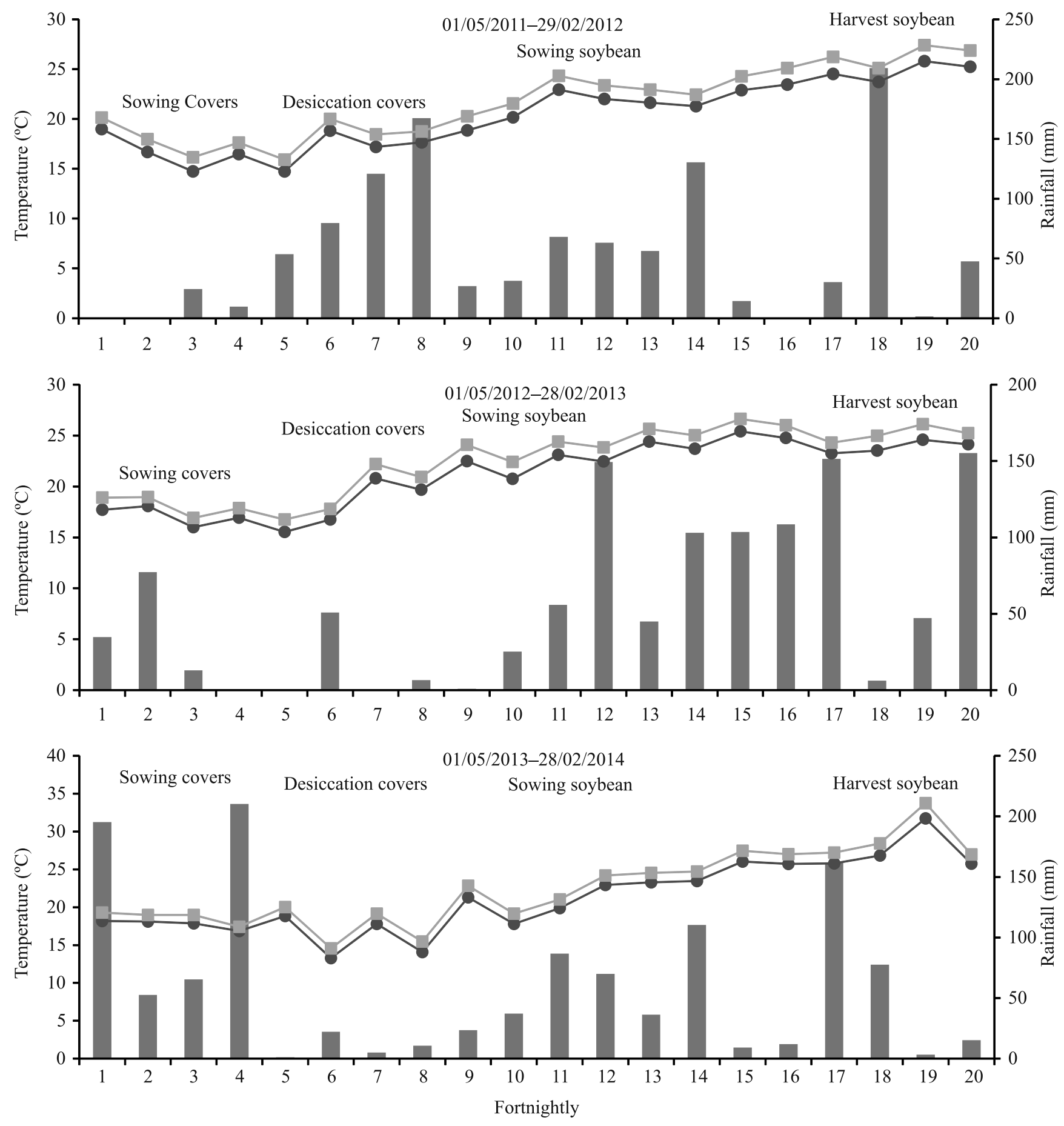

Rainfall - - Minimum temperature - - Maximum temperature

Figure 1. Rainfall and minimum and maximum mean temperatures during the cycles of the cover crops and soybean (Glycine max), in the 2011/2012, 2012/2013, and 2013/2014 crop seasons. Source: INMET (2015). 
Specifically for soybean, the variables assessed over the three crop years were: plant height at the V8 stage $(\mathrm{cm})$, final plant height $(\mathrm{cm})$, first pod height $(\mathrm{cm})$, number of branches, total chlorophyll index obtained with the aid of the ClorofiLOg (Falker, Porto Alegre, RS, Brazil), number of pods, 100-seed mass (g), and yield $\left(\mathrm{kg} \mathrm{ha}^{-1}\right)$.

The percentages of soil cover 30 days after sowing and of straw remaining on soil surface 45 and 90 days after desiccation were determined by photographs, which were taken in a $0.50 \times 0.50 \mathrm{~m}$ template, positioned at $1.0 \mathrm{~m}$ above soil level, according to Ziech et al. (2015), so that all the evaluations were carried out in the same area. In the laboratory, a grid of 100 points was superimposed on the photos, using Corel Draw X5 (Corel Corporation, 2002), and the points corresponding to covered soil area were counted.

Regarding the other variables, for plant height determination, eight plants were randomly chosen inside the working area of each plot and measured using a wooden ruler. The number of pods per plant was counted at the R8 stage, also in eight plants inside each plot. Total yield $\left(\mathrm{kg} \mathrm{ha}^{-1}\right)$ was estimated for each treatment and replicate, whereas 100 -seed mass was determined by weighing eight subsamples in each replicate in the field. In order to obtain yield and 100seed mass, the moisture content was corrected to $13 \%$ on a wet basis.

Data were tested for normality using the ShapiroWilk test and then were subjected to the analysis of variance using the F-test, at 5\% probability. A joint analysis was applied to the data, using uniform residual variances as a criterion, which could not exceed the 7:1 ratio (Banzatto \& Kronka, 2006). The differences between and within treatments were evaluated with Tukey's test, at $5 \%$ probability. The software used was Sisvar (Ferreira, 2011).

\section{Results and Discussion}

The joint analysis revealed a significant interaction between soil cover percentage and crop season; therefore, the data presented here refer to the treatments within each repeated harvest (2011/2012, 2012/2013, and 2013/2014). However, since the treatments had no significant effect on soybean yield, only their overall means were presented.

Soil cover percentage 30 days after sowing did not differ between harvests, but differed between cover species. Forage radish and the intercrop black oat + forage radish had the highest percentage of soil cover. This result may have been due to the faster growth of these species, which also show low nutrient demand and high tolerances to climatic adversities (Fontaneli et al., 2009; Cremonez et al., 2013). Vetch and ryegrass provided the lowest soil cover, revealing slower initial growth rates than forage radish and black oat + forage radish (Table 1).

The dry matter yield of the cover crops and of wheat was also affected by crop seasons. In general, black oat, white oat, vetch, and ryegrass had greater dry matter yield in the 2011/2012 season than in 2012/2013 and $2013 / 2014$. For forage radish and the intercrop black oat + forage radish, dry mater yield was greater in 2012/2013 and 2013/2014. Wheat yield, however, did not differ significantly between crop seasons.

In 2011/2012, white oat, black oat, vetch, and black oat + forage radish produced $27,12,7.5$, and $27 \%$, respectively, more dry matter than the standard wheat crop. Forage radish and black oat + forage radish had 43.0 and $45.0 \%$ higher dry matter yield than wheat in 2012/2013, respectively, and both had $30.0 \%$ higher yield in 2013/2014 (Table 1).

It should also be noted that forage radish can produce high amounts of dry matter mass. Carneiro et al. (2008), for example, reported values $5,290 \mathrm{~kg} \mathrm{ha}^{-1}$, and Heinz et al. (2011) of 5,586 $\mathrm{kg} \mathrm{ha}^{-1}$. However, the yields found here were higher, probably because dry matter yield was estimated 20 days after full flowering in the present study and at flowering in those works. Andreotti et al. (2008) pointed out that a proper notillage system requires a minimum of $6,000 \mathrm{~kg} \mathrm{ha}^{-1}$ dry mass covering the soil. Therefore, the intercrop black oat + forage radish is an excellent option for succession systems, since it produced dry mater yield above this minimum in the three crop seasons.

The straw from black oat, white oat, and ryegrass remained the longest on soil surface 45 days after desiccation, in all seasons, and 90 days after desiccation, in the 2011/2012 season. However, in 2012/2013 and 2013/2014, white oat straw stood out (Table 2). This is explained by the fact that white oat and ryegrass usually have higher $\mathrm{C} / \mathrm{N}$ ratios in their residues (Teixeira et al., 2011), reducing the decomposition rate of straw and providing a higher percentage of soil cover over time.

In contrast, forage radish straw covered a significantly lower percentage of soil than the other species at 45 and 90 days after desiccation, in all crop 
seasons (Table 2). This result is attributed to the low $\mathrm{C} / \mathrm{N}$ ratio, ranging from 11 to $17 / 1$, of forage radish (Carneiro et al., 2008; Ziech et al., 2015). According to Calonego et al. (2012), cover crops with $\mathrm{C} / \mathrm{N}$ ratios lower than 20 produce straw that rapidly decomposes, reducing the percentage of soil cover.

The initial height of soybean was affected by cover crop species in 2012/2013 and 2013/2014, but not in 2011/2012. In 2013/2014, taller soybean plants were observed both at the beginning (V8 stage) and at end of the crop season (Table 3). This significant difference in relation to the other seasons may have been due to well-distributed rainfall during the soybean cycle then (Figure 1).

Vetch was the cover crop species that most negatively influenced the initial and final heights of soybean in 2011/2012 and 2012/2013, but did not affect it in
2013/2014 (Table 3). Similar findings were reported by Santos et al. (2013b), probably due to the species allelopathic effects (Fujii, 2003). Black oat and the intercrop black oat + forage radish increased the final height of soybean more than vetch, wheat, and ryegrass in 2011/2012 and 2012/2013; however, soybean height was similar across all treatments in 2013/2014. This inconsistent behavior may have been caused by the different climatic conditions along the seasons (Figure 1). In addition, soybean height at the initial and final growth stages may have been affected by the pattern of nutrient mineralization in the plant residues. Crusciol et al. (2008), for example, found that black oat crop residues release different amounts of nutrients: $98 \%$ of the initial potassium content, but only $45 \%$ of the initial nitrogen content 53 days after management.

Table 1. Soil cover 30 days after cover crops were planted, as well as their dry matter yield 20 days after full bloom, in the 2011/2012, 2012/2013, and 2013/2014 crop seasons ${ }^{(1)}$.

\begin{tabular}{lllcc}
\hline Treatment & $\begin{array}{c}\text { Soil cover } \\
(\%)\end{array}$ & \multicolumn{3}{c}{ Dry matter yield $\left(\mathrm{kg} \mathrm{ha}^{-1}\right)$} \\
\cline { 3 - 5 } & $64.50 \mathrm{C}$ & $6,490 \mathrm{Aa}$ & $2012 / 2013$ & $2013 / 2014$ \\
\hline Black oat (Avena strigosa) & $71.00 \mathrm{BC}$ & $7,900 \mathrm{Aa}$ & $3,980 \mathrm{Bb}$ & $3,303 \mathrm{Bab}$ \\
White oat (Avena sativa) & $47.83 \mathrm{D}$ & $5,760 \mathrm{Bb}$ & $5,783 \mathrm{Bb}$ \\
Wheat (Triticum aestivum) & $34.33 \mathrm{E}$ & $6,260 \mathrm{Aa}$ & $3,810 \mathrm{Ba}$ & $5,133 \mathrm{Ba}$ \\
Vetch (Vicia sativa) & $82.75 \mathrm{~A}$ & $3,440 \mathrm{Bb}$ & $4,040 \mathrm{Bb}$ & $7,360 \mathrm{Bab}$ \\
Forage radish (Raphanus sativus) & $25.25 \mathrm{E}$ & $5,335 \mathrm{Aa}$ & $3,675 \mathrm{Aa}$ & $2,503 \mathrm{Bab}$ \\
Ryegrass (Lolium multiflorum) & $77.75 \mathrm{AB}$ & $7,900 \mathrm{Ab}$ & $6,943 \mathrm{ABa}$ & $7,469 \mathrm{Aa}$ \\
Black oat + forage radish & 12.76 & & 15.68 & \\
\hline Coefficient of variation (\%) & & & & \\
\hline
\end{tabular}

(1)Means followed by equal letters, uppercase in the columns and lowercase in the rows, do not differ significantly by Tukey's test, at $5 \%$ probability.

Table 2. Soil cover by cover crops 45 and 90 days after desiccation, in the 2011/2012, 2012/2013, and 2013/2014 crop seasons ${ }^{(1)}$.

\begin{tabular}{|c|c|c|c|c|c|c|}
\hline \multirow[t]{2}{*}{ Treatment } & \multicolumn{3}{|c|}{ Soil cover 45 days after desiccation (\%) } & \multicolumn{3}{|c|}{ Soil cover 90 days after desiccation (\%) } \\
\hline & $2011 / 2012$ & $2012 / 2013$ & $2013 / 2014$ & $2011 / 2012$ & $2012 / 2013$ & $2013 / 2014$ \\
\hline Black oat (Avena strigosa) & $90.00 \mathrm{Ba}$ & $77.50 \mathrm{Db}$ & $88.75 \mathrm{CDa}$ & $76.25 \mathrm{~B}$ & $61.75 \mathrm{E}$ & $75.75 \mathrm{C}$ \\
\hline White oat (Avena sativa) & $97.25 \mathrm{Aa}$ & $93.25 \mathrm{Abb}$ & $96.75 \mathrm{Abab}$ & $87.25 \mathrm{Aa}$ & $80.75 \mathrm{Ab}$ & 84.00Aab \\
\hline Wheat (Triticum aestivum) & $92.00 \mathrm{Ba}$ & $83.50 \mathrm{Cb}$ & $91.75 \mathrm{Bca}$ & $76.50 \mathrm{Bb}$ & $71.00 \mathrm{BCc}$ & $80.25 \mathrm{Aba}$ \\
\hline Vetch (Vicia sativa) & 94.00Aba & $88.50 \mathrm{BCb}$ & $94.00 \mathrm{Aba}$ & $78.75 \mathrm{Ba}$ & $68.00 \mathrm{CDb}$ & $78.50 \mathrm{Bca}$ \\
\hline Forage radish (Raphanus sativus) & $48.25 \mathrm{Da}$ & $36.00 \mathrm{~Eb}$ & $52.00 \mathrm{Ea}$ & $13.50 \mathrm{Da}$ & $8.50 \mathrm{Fb}$ & $12.50 \mathrm{Ea}$ \\
\hline Ryegrass (Lolium multiflorum) & $97.25 \mathrm{Aa}$ & $94.25 \mathrm{Aa}$ & $97.25 \mathrm{Aa}$ & $86.50 \mathrm{Aa}$ & $74.50 \mathrm{Bc}$ & $81.25 \mathrm{Abb}$ \\
\hline Black oat + forage radish & $82.00 \mathrm{Ca}$ & $74.75 \mathrm{Db}$ & $83.75 \mathrm{Da}$ & $70.50 \mathrm{Ca}$ & 65.00Deb & $68.50 \mathrm{Da}$ \\
\hline Coefficient of variation (\%) & \multicolumn{3}{|c|}{2.79} & \multicolumn{3}{|c|}{3.02} \\
\hline
\end{tabular}


Overall, the variables height of the first pod and number of branches were not significantly affected by the treatments. However, in 2011/2012, pod height was greater when preceded by white oat and lower after vetch (Table 4). In 2013/2014, a higher number of branches and a lower first pod height were observed.

There was also a higher number of pods when the predecessor crop was forage radish, compared with ryegrass, in 2012/2013 (Table 5). However, cover species had no influence on this variable in the other seasons. Regarding crop season, a lower number of pods was obtained in 2011/2012, which may be due to the long drought period then (Figure 1), which negatively influenced soybean yield (Table 6).

The highest soybean chlorophyll contents were found in 2011/2012 (Table 5), but there was no effect of cover crop species in this season. In 2012/2013 and
2013/2014, however, a higher chlorophyll content was observed in succession to black oat + forage radish, compared with wheat and ryegrass.

The cover crops had no effect on 100-seed mass (Table 6), which showed the highest average in the 2013/2014 season. In 2011/2012, the different treatments also did not affect soybean yield; however, in comparison with the standard management with wheat, soybean yields were 26\% higher in 2012/2013 when sown both after black oat and black oat + forage radish, and 26 and 27\% higher in 2013/2014, respectively.

The greater soybean yield with black oat and black oat + forage radish as cover crops, in 2012/2013 and 2013/2014, may be explained by the peculiar characteristics of these two systems. The roots of both black oat and forage radish are capable of growing in compacted soil layers, which increases soil exploration

Table 3. Initial (at the V8 stage) and final heights of soybean (Glycine max) grown after cover crops, in the 2011/2012, 2012/2013, and 2013/2014 crop seasons $^{(1)}$.

\begin{tabular}{|c|c|c|c|c|c|c|}
\hline \multirow[t]{2}{*}{ Treatment } & \multicolumn{3}{|c|}{ Initial plant height at V8 $(\mathrm{cm})$} & \multicolumn{3}{|c|}{ Final plant height (cm) } \\
\hline & $2011 / 2012$ & $2012 / 2013$ & $2013 / 2014$ & $2011 / 2012$ & $2012 / 2013$ & $2013 / 2014$ \\
\hline Black oat (Avena strigosa) & $51.24 \mathrm{Ab}$ & $51.30 \mathrm{Ab}$ & $57.82 \mathrm{Aa}$ & $100.16 \mathrm{Aa}$ & $63.35 \mathrm{Ab}$ & $103.28 \mathrm{Aa}$ \\
\hline White oat (Avena sativa) & $49.55 \mathrm{Ab}$ & $49.10 \mathrm{ABb}$ & $55.87 \mathrm{ABCa}$ & $98.75 \mathrm{Aa}$ & $59.70 \mathrm{ABb}$ & $103.28 \mathrm{Aa}$ \\
\hline Wheat (Triticum aestivum) & $46.52 \mathrm{Aab}$ & $43.05 \mathrm{BCb}$ & $51.33 \mathrm{ABCa}$ & $87.79 \mathrm{Bb}$ & $54.75 \mathrm{ABc}$ & $103.06 \mathrm{Aa}$ \\
\hline Vetch (Triticum aestivum) & $45.05 \mathrm{Aab}$ & $40.10 \mathrm{Cb}$ & $49.12 \mathrm{Ca}$ & $89.62 \mathrm{Bb}$ & $51.10 \mathrm{Bc}$ & $101.22 \mathrm{Aa}$ \\
\hline Forage radish (Raphanus sativus) & $50.37 \mathrm{Ab}$ & $50.75 \mathrm{Ab}$ & $57.11 \mathrm{ABa}$ & $93.25 \mathrm{ABa}$ & $59.65 \mathrm{ABb}$ & 99.37Aa \\
\hline Ryegrass (Lolium multiflorum) & 45.72Aab & $41.45 \mathrm{Cb}$ & $50.13 \mathrm{BCa}$ & $92.41 \mathrm{ABb}$ & $52.95 \mathrm{Bc}$ & $100.03 \mathrm{Aa}$ \\
\hline Black oat + forage radish & $51.15 \mathrm{Ab}$ & $52.30 \mathrm{Aab}$ & $58.27 \mathrm{Aa}$ & $94.29 \mathrm{ABb}$ & $62.08 \mathrm{Ac}$ & $105.00 \mathrm{Aa}$ \\
\hline Coefficient of variation $(\%)$ & \multicolumn{3}{|c|}{7.03} & \multicolumn{3}{|c|}{4.93} \\
\hline
\end{tabular}

${ }^{(1)}$ Means followed by equal letters, uppercase in the columns and lowercase in the rows, do not differ significantly by Tukey's test, at $5 \%$ probability.

Table 4. Number of branches and first pod height of soybean (Glycine max) grown after cover crops, in the 2011/2012, 2012/2013, and 2013/2014 crop seasons $^{(1)}$.

\begin{tabular}{|c|c|c|c|c|c|c|}
\hline \multirow[t]{2}{*}{ Treatment } & \multicolumn{3}{|c|}{ Number of branches } & \multicolumn{3}{|c|}{ First pod height $(\mathrm{cm})$} \\
\hline & $2011 / 2012$ & $2012 / 2013$ & $2013 / 2014$ & $2011 / 2012$ & $2012 / 2013$ & $2013 / 2014$ \\
\hline Black oat (Avena strigosa) & $1.74 \mathrm{Ab}$ & $3.85 \mathrm{Aa}$ & $4.13 \mathrm{Aa}$ & $15.41 \mathrm{ABb}$ & 18.19Aa & $11.18 \mathrm{Ac}$ \\
\hline White oat (Avena sativa) & $2.20 \mathrm{Ac}$ & $3.60 \mathrm{Ab}$ & $4.23 \mathrm{Aa}$ & $16.58 \mathrm{Ab}$ & 18.77Aa & $12.05 \mathrm{Ac}$ \\
\hline Wheat (Triticum aestivum) & $2.04 \mathrm{Ac}$ & $3.40 \mathrm{Ab}$ & $4.05 \mathrm{Aa}$ & $16.04 \mathrm{ABb}$ & $18.50 \mathrm{Aa}$ & $11.65 \mathrm{Ac}$ \\
\hline Vetch (Vicia sativa) & $2.12 \mathrm{Ac}$ & $3.25 \mathrm{Ab}$ & $4.02 \mathrm{Aa}$ & $14.79 \mathrm{Bb}$ & $17.88 \mathrm{Aa}$ & $10.71 \mathrm{Ac}$ \\
\hline Forage radish (Raphanus sativus) & $2.29 \mathrm{Ab}$ & $3.90 \mathrm{Aa}$ & $4.42 \mathrm{Aa}$ & $16.29 \mathrm{ABb}$ & $18.63 \mathrm{Aa}$ & $11.83 \mathrm{Ac}$ \\
\hline Ryegrass (Lolium multiflorum) & $2.25 \mathrm{Ac}$ & $3.45 \mathrm{Ab}$ & 4.18Aa & $15.58 \mathrm{ABb}$ & $18.27 \mathrm{Aa}$ & $11.30 \mathrm{Ac}$ \\
\hline Black oat + forage radish & $1.62 \mathrm{Ab}$ & $3.70 \mathrm{Aa}$ & $4.00 \mathrm{Aa}$ & $15.54 \mathrm{ABb}$ & $18.25 \mathrm{Aa}$ & $11.27 \mathrm{Ac}$ \\
\hline Coefficient of variation ( $\%)$ & \multicolumn{3}{|c|}{10.68} & \multicolumn{3}{|c|}{4.74} \\
\hline
\end{tabular}

${ }^{(1)}$ Means followed by equal letters, uppercase in the columns and lowercase in the rows, do not differ significantly by Tukey's test, at $5 \%$ probability. 
Table 5. Number of pods and total chlorophyll index of soybean (Glycine max) grown after cover crops, in the 2011/2012,

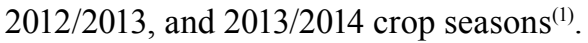

\begin{tabular}{|c|c|c|c|c|c|c|}
\hline \multirow[t]{2}{*}{ Treatment } & \multicolumn{3}{|c|}{ Number of pods } & \multicolumn{3}{|c|}{ Total chlorophyll index } \\
\hline & $2011 / 2012$ & $2012 / 2013$ & $2013 / 2014$ & $2011 / 2012$ & $2012 / 2013$ & $2013 / 2014$ \\
\hline Black oat (Avena strigosa) & $37.79 \mathrm{Ab}$ & $49.35 \mathrm{ABa}$ & $39.28 \mathrm{Ab}$ & $55.86 \mathrm{Aa}$ & $49.44 \mathrm{ABc}$ & $52.65 \mathrm{ABCb}$ \\
\hline White oat (Avena sativa) & $38.91 \mathrm{Ab}$ & $50.15 \mathrm{ABa}$ & $44.62 \mathrm{Aa}$ & $54.80 \mathrm{Aa}$ & $47.33 \mathrm{BCc}$ & $51.06 \mathrm{ABCb}$ \\
\hline Wheat (Triticum aestivum) & $35.79 \mathrm{Ac}$ & $50.70 \mathrm{ABa}$ & $41.84 \mathrm{Ab}$ & $54.29 \mathrm{Aa}$ & $46.31 \mathrm{Cc}$ & $50.30 \mathrm{Cb}$ \\
\hline Vetch (Vicia sativa) & $37.25 \mathrm{Ab}$ & $50.60 \mathrm{ABa}$ & $45.87 \mathrm{Aa}$ & $56.29 \mathrm{Aa}$ & 48.76ABCc & $52.14 \mathrm{ABCb}$ \\
\hline Forage radish (Raphanus sativus) & $38.37 \mathrm{Ac}$ & $53.90 \mathrm{Aa}$ & $44.12 \mathrm{Ab}$ & 55.99Aa & $49.72 \mathrm{ABc}$ & $52.85 \mathrm{ABb}$ \\
\hline Ryegrass (Lolium multiflorum) & $39.12 \mathrm{Ab}$ & $45.35 \mathrm{Ba}$ & 45.34Aa & $54.38 \mathrm{Aa}$ & $46.49 \mathrm{Cc}$ & $50.44 \mathrm{BCb}$ \\
\hline Black oat + forage radish & $36.08 \mathrm{Ac}$ & $51.45 \mathrm{ABa}$ & $42.31 \mathrm{Ab}$ & $55.52 \mathrm{Aa}$ & $50.31 \mathrm{Ac}$ & $53.30 \mathrm{Ab}$ \\
\hline Coefficient of variation (\%) & \multicolumn{3}{|c|}{7.58} & \multicolumn{3}{|c|}{2.27} \\
\hline
\end{tabular}

(1)Means followed by equal letters, uppercase in the columns and lowercase in the rows, do not differ significantly by Tukey's test, at $5 \%$ probability.

Table 6. Yield and 100-seed mass of soybean (Glycine max) grown after cover crops, in the 2011/2012, 2012/2013, and 2013/2014 crop seasons $^{(1)}$.

\begin{tabular}{|c|c|c|c|c|c|c|}
\hline \multirow{2}{*}{ Treatment } & \multicolumn{3}{|c|}{ Yield $\left(\mathrm{kg} \mathrm{ha}^{-1}\right)$} & \multicolumn{3}{|c|}{ 100-seed mass (g) } \\
\hline & $2011 / 2012$ & $2012 / 2013$ & $2013 / 2014$ & $2011 / 2012$ & $2012 / 2013$ & $2013 / 2014$ \\
\hline Black oat (Avena strigosa) & $1,974.78 \mathrm{Ab}$ & $4,862.16 \mathrm{Aa}$ & $4,226.14 \mathrm{Aa}$ & $10.08 \mathrm{Ac}$ & $15.22 \mathrm{Ab}$ & $17.51 \mathrm{Aa}$ \\
\hline White oat (Avena sativa) & $2,024.22 \mathrm{Ab}$ & $4,501.31 \mathrm{ABa}$ & $3,741.33 \mathrm{ABa}$ & $10.44 \mathrm{Ab}$ & $15.07 \mathrm{Aa}$ & $15.86 \mathrm{Aa}$ \\
\hline Wheat (Triticum aestivum) & $2,059.91 \mathrm{Ab}$ & $3,594.62 \mathrm{Ba}$ & $3,106.26 \mathrm{Ba}$ & $10.30 \mathrm{Ab}$ & $14.99 \mathrm{Aa}$ & $15.57 \mathrm{Aa}$ \\
\hline Vetch (Vicia sativa) & $2,032.49 \mathrm{Ac}$ & $4,367.58 \mathrm{ABa}$ & $3,453.33 \mathrm{ABb}$ & $10.25 \mathrm{Ac}$ & $15.21 \mathrm{Ab}$ & $16.91 \mathrm{Aa}$ \\
\hline Forage radish (Raphanus sativus) & $2,010.13 \mathrm{Ac}$ & $4,350.60 \mathrm{ABa}$ & $3,317.19 \mathrm{ABb}$ & $9.79 \mathrm{Ab}$ & $15.11 \mathrm{Aa}$ & $15.34 \mathrm{Aa}$ \\
\hline Ryegrass (Lolium multiflorum) & $1,986.22 \mathrm{Ac}$ & $4,313.51 \mathrm{ABa}$ & $3,306.39 \mathrm{ABb}$ & $10.40 \mathrm{Ac}$ & $14.66 \mathrm{Ab}$ & $16.10 \mathrm{Aa}$ \\
\hline Black oat + forage radish & $1,987.00 \mathrm{Ab}$ & 4,879.91Aa & $4,237.85 \mathrm{Aa}$ & $10.11 \mathrm{Ab}$ & $15.90 \mathrm{Aa}$ & $15.18 \mathrm{Aa}$ \\
\hline Coefficient of variation (\%) & \multicolumn{3}{|c|}{13.82} & \multicolumn{3}{|c|}{5.36} \\
\hline
\end{tabular}

and may improve soil physical conditions (Müller et al., 2001; Silva \& Rosolem, 2002; Cardoso et al., 2014). Furthermore, $34 \%$ of the initial content of black oat residues persists 53 days after management, and approximately $50 \%$ of the nutrients $\mathrm{N}, \mathrm{P}, \mathrm{Ca}$, and $\mathrm{S}$ are probably released gradually to the soil after 50 days, benefitting the subsequent crops (Crusciol et al., 2008).

The increase in soybean yield with the use of cover crops, compared with the standard management with wheat, may be related to a series of factors, such as: suppression of weeds by straw or by allelopathic effects (Monquero et al., 2009; Pereira et al., 2011); higher root growth rates (Silva \& Rosolem, 2002); soybean nodulation (Fontaneli et al., 2000); improvement of soil physical and chemical properties, as well as of nutrient cycling (Crusciol et al., 2008; Costa et al., 2015); and increased soil protection with residue permanence (Ziech et al., 2015).
The obtained results show that most of the nonsignificant differences in soybean development and yield were observed in the first crop season (2011/2012), suggesting that the benefits of the productive systems may begin to manifest themselves latter.

\section{Conclusions}

1. Forage radish (Raphanus sativus) and the intercrop black oat (Avena strigosa) + forage radish show greater dry matter productivity.

2. White oat (Avena sativa) and ryegrass (Lolium multiflorum) show the highest soil cover rate over time, compared with the other cover crops evaluated.

3. Soybean (Glycine max) yield is increased when planted in succession to winter cover crops, mostly after the second year of the adoption of the system.

Pesq. agropec. bras., Brasília, v.53, n.8, p.909-917, Aug. 2018 DOI: 10.1590/S0100-204X2018000800005 
4. Black oat and the intercrop black oat + forage radish have the greatest potential to increase soybean yields.

\section{Acknowledgments}

To Mr. Benjamin Krenchinski, for providing the experimental area; and to Universidade Federal do Paraná, for support in conducting the experiment.

\section{References}

ANDREOTTI, M.; ARALDI, M.; GUIMARÃES, V.F.; FURLANI JUNIOR, E.; BUZETTI, S. Produtividade do milho safrinha e modificações químicas de um Latossolo em sistema plantio direto em função de espécies de cobertura após calagem superficial. Acta Scientiarum. Agronomy, v.30, p.109-115, 2008. DOI: 10.4025/actasciagron.v30i1.1158.

BANZATTO, D.A.; KRONKA, S. do N. Experimentação agrícola. 4.ed. Jaboticabal: Funep, 2006.

CALONEGO, J.C.; GIL, F.C.; ROCCO, V.F.; SANTOS, E.A. dos. Persistência e liberação de nutrientes da palha de milho, braquiária e labe-labe. Bioscience Journal, v.28, p.770-781, 2012.

CARDOSO, R.A.; BENTO, A.S.; MORESKI, H.M.; GASPAROTTO, F. Influência da adubação verde nas propriedades físicas e biológicas do solo e na produtividade da cultura de soja. Semina: Ciências Biológicas e da Saúde, v.35, p.51-60, 2014. DOI: $10.5433 / 1679-0367.2014 v 35 n 2 p 51$.

CARNEIRO, M.A.C.; CORDEIRO, M.A.S.; ASSIS, P.C.R.; MORAES, E.S.; PEREIRA, H.S.; PAULINO, H.B.; SOUZA, E.D. de. Produção de fitomassa de diferentes espécies de cobertura e suas alterações na atividade microbiana de solo de cerrado. Bragantia, v.67, p.455-462, 2008. DOI: 10.1590/S000687052008000200021 .

COREL CORPORATION. Corel Draw, version X5.633: project planning software. 2002. CD-ROM.

COSTA, N.R.; ANDREOTTI, M.; ULIAN, N. de A.; COSTA, B.S.; PARIZ, C.M.; CAVASANO, F.A.; TEIXEIRA FILHO, M.C.M. Produtividade da soja sobre palhada de forrageiras semeadas em diferentes épocas e alterações químicas no solo. Revista Brasileira de Ciências Agrárias, v.10, p.8-16, 2015. DOI: 10.5039/agraria.v10ila3842.

CREMONEZ, P.A.; FEIDEN, A.; CREMONEZ, F.E.; ROSSI, E. de; ANTONELLI, J.; NADALETI, W.C.; TOMASSONI, F. Nabo forrageiro: do cultivo a produção de biodiesel. Acta Iguazu, v.2, p.64-72, 2013.

CRUSCIOL, C.A.C.; MORO, E.; LIMA, E. do V.; ANDREOTTI, M. Taxas de decomposição e de liberação de macronutrientes da palhada de aveia preta em plantio direto. Bragantia, v.67, p.481489, 2008. DOI: 10.1590/S0006-87052008000200024.

DEBIASI, H.; LEVIEN, R.; TREIN, C.R.; CONTE, O.; KAMIMURA, K.M. Produtividade de soja e milho após coberturas de inverno e descompactação mecânica do solo. Pesquisa Agropecuária Brasileira, v.45, p.603-612, 2010. DOI: 10.1590/S0100-204X2010000600010.

FERREIRA, D.F. Sisvar: a computer statistical analysis system. Ciência e Agrotecnologia, v.35, p.1039-1042, 2011. DOI: 10.1590/ S1413-70542011000600001.

FONTANELI, R.S.; FONTANELI, R.S.; SANTOS, H.P. dos; NASCIMENTO JUNIOR, A. do; MINELLA, E.; CAIERÃO, E. Rendimento e valor nutritivo de cereais de inverno de duplo propósito: forragem verde e silagem ou grãos. Revista Brasileira de Zootecnia, v.38, p.2116-2120, 2009. DOI: 10.1590/S151635982009001100007.

FONTANELI, R.S.; SANTOS, H.D. dos; VOSS, M.; AMBROSI, I. Rendimento e nodulação de soja em diferentes rotações de espécies anuais de inverno sob plantio direto. Pesquisa Agropecuária Brasileira, v.35, p.349-355, 2000. DOI: 10.1590/ S0100-204X2000000200014.

FUJII, Y. Allelopathy in the natural and agricultural ecosystems and isolation of potent allelochemicals from Velvet bean (Mucuna pruriens) and Hairy vetch (Vicia villosa). Biological Sciences in Space, v.17, p.6-13, 2003. DOI: 10.2187/bss.17.6.

HEINZ, R.; GARBIATE, M.V.; VIEGAS NETO, A.L.; MOTA, L.H. de S.; CORREIA, A.M.P.; VITORINO, A.C.T. Decomposição e liberação de nutrientes de resíduos culturais de crambe e nabo forrageiro. Ciência Rural, v.41, p.1549-1555, 2011. DOI: 10.1590/ S0103-84782011000900010.

INMET. Instituto Nacional de Meteorologia. Dados climáticos. Available at: <http://www.inmet.gov.br/portal/>. Accessed on: Feb. 12015

MONQUERO, P.A.; AMARAL, L.R.; INÁCIO, E.M.; BRUNHARA, J.P.; BINHA, D.P.; SILVA, P.V.; SILVA, A.C. Efeito de adubos verdes na supressão de espécies de plantas daninhas. Planta Daninha, v.27, p.85-95, 2009. DOI: 10.1590/ S0100-83582009000100012.

MÜLLER, M.M.L.; CECCON, G.; ROSOLEM, C.A. Influência da compactação do solo em subsuperfície sobre o crescimento aéreo e radicular de plantas de adubação verde de inverno. Revista Brasileira de Ciência do Solo, v.25, p.531-538, 2001. DOI: $10.1590 / \mathrm{S} 0100-06832001000300002$.

PEREIRA, R.A.; ALVES, P.L. da C.A.; CORREAA, M.P.; DIAS, T.C. de S. Influência da cobertura de aveia-preta e milheto sobre comunidade de plantas daninhas e produção de soja. Revista Brasileira de Ciências Agrárias, v.6, p.1-10, 2011. DOI: 10.5039/ agraria.v6i1a545

SANTOS, H.G. dos; JACOMINE, P.K.T.; ANJOS, L.H.C. dos; OLIVEIRA, V.A. de; LUMBRERAS, J.F.; COELHO, M.R.; ALMEIDA, J.A. de; CUNHA, T.J.F.; OLIVEIRA, J.B. de. Sistema de classificação dos solos. 3.ed. rev. e ampl. Brasília: Embrapa, 2013a. 353p.

SANTOS, H.P. dos; REIS, E.M. Efeitos de culturas de inverno sobre o rendimento de grãos e sobre a estatura de plantas da soja. Pesquisa Agropecuária Brasileira, v.26, p.729-735, 1991.

SANTOS, H.P.; FONTANELI, R.S.; SPERA, S.T.; MALDANER, G.L. Rendimento de grãos de soja em diferentes sistemas de produção integração lavoura-pecuária. Revista Brasileira de 
Ciências Agrárias, v.8, p.49-56, 2013b. DOI: 10.5039/agraria. v8ila2077.

SILVA, R.H. da; ROSOLEM, C.A. Crescimento radicular de soja em razão da sucessão de cultivos e da compactação do solo. Pesquisa Agropecuária Brasileira, v.37, p.855-860, 2002. DOI: 10.1590/S0100-204X2002000600015.

TECNOLOGIAS de produção de soja: região Central do Brasil 2011. Londrina: Embrapa Soja, 2010. 255p. (Embrapa Soja. Sistemas de produção, 14).
TEIXEIRA, M.B.; LOSS, A.; PEREIRA, M.G.; PIMENTEL, C. Decomposição e liberação de nutrientes da parte aérea de plantas de milheto e sorgo. Revista Brasileira de Ciência do Solo, v.35, p.867-876, 2011. DOI: 10.1590/S010006832011000300021.

ZIECH, A.R.D.; CONCEIÇÃO, P.C.; LUCHESE, A.V.; BALIN, N.M.; CANDIOTTO, G.; GARMUS, T.G. Proteção do solo por plantas de cobertura de ciclo hibernal na região Sul do Brasil. Pesquisa Agropecuária Brasileira, v.50, p.374-382, 2015. DOI: 10.1590/S0100-204X2015000500004.

$\overline{\text { Received on August 15, } 2016 \text { and accepted on June 13, } 2017}$ 